\title{
The Application of Membrane Separation Processes as Environmental Friendly Methods in the Beet Sugar Production
}

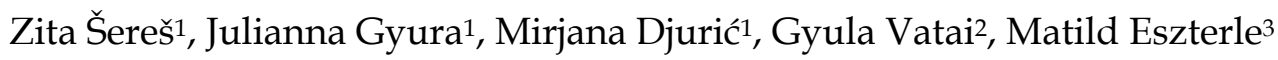 \\ ${ }^{1}$ University of Novi Sad, Faculty of Technology \\ Serbia \\ ${ }^{2}$ Corvinus University, Department of Food Engineering \\ Hungary \\ ${ }^{3}$ Research Institute of Hungarian Sugar Industry \\ Hungary
}

\section{Introduction}

The sugar industry is one of the key segments of the food industry. This industry is also well known as one of the most energy-intensive in the field of food and chemical industry. In 1999, the total quantity of produced sugar was summarized. It was reported that the production reached 16700000 tones, while the total value of the produced sugar was 8924 million EUR. A significant quantity of thermal energy was consumed for the evaporation and beet pulp drying, as well as electrical energy needed for the pumps and for driving the centrifuges. According to CEFS, specific energy consumption was $31.49 \mathrm{kWh} / 100 \mathrm{~kg}$ beet in 1998 (IPPC, 2003). In a Greek study, a figure of $280 \mathrm{kWh} / \mathrm{t}$ is given for the electrical part of the energy consumption in sugar manufacturing (IPPC, 2003). While the overall water used is about $15 \mathrm{~m}^{3} / \mathrm{t}$ sugar beet processed, the consumption of fresh water is $0.25-0.4 \mathrm{~m}^{3} / \mathrm{t}$ sugar beet processed, or even less in modern sugar factories. Water consumption depends on the activities of each installation, e.g. more water is consumed in an installation that extracts and refines sugar beet compared to the one that does only one of these activities (IPPC, 2003). For example, the consumption of water in Austria was reported at a level of 1.5 $\mathrm{m}^{3} / \mathrm{t}$ of sugar beet processed, which is equivalent to $9 \mathrm{~m}^{3} / \mathrm{t}$ of produced sugar (IPPC, 2003). The transport water has high organic contamination due to the soil and sugar from damaged beets. Its COD is $5000-20000 \mathrm{mg} / \mathrm{L}$. Waste water with high BOD levels is produced in large volumes (IPPC, 2003).

Despite the fact that the sugar industry is one of the causes of the environmental pollution, not enough has been done on its improvement. The technology applied in almost all European sugar factories is based on the traditional principles and methods. The major steps in the traditional sugar beet processing are (Poel Van der et al., 1998):

i) Pre treatment - Washing and slicing of the sugar-beets into cosettes are the initial operations; 
ii) Extraction - The sugar is counter-currently extracted from beet cosettes to obtain raw juice and beet pulp. The raw juice is thermally unstable at temperatures above $85{ }^{\circ} \mathrm{C}$. The beet pulp can be used as cattle feed or can be modified to obtain fibers for human feed;

iii) Beet juice purification - Milk of lime and karbonation gas $\mathrm{CO}_{2}$, both produced in a separate facility, are applied. Coke and limestone are used for the production of $\mathrm{CaO}$ and $\mathrm{CO}_{2}$. The lime usage of the conventional process is about $2 \% /$ beet. Classical juice purification consists of liming, carbonation, sludge separation and sulphitation. However, this process removes only a part of non sugars from the sugar juice (proteins, pectins, inorganic salts and colouring substances);

iv) Beet juice concentration - By multi-effect evaporation the thin juice with a dry substance content of $14-16 \%$ is concentrated to thick juice with $60-75 \%$ of dry matter;

v) Crystallization - Further evaporation of water leads to crystallization and growth of crystals. Sugar crystals are separated by centrifuge from the syrup. The separation occurs in three stages. The molasses is the by-product from which the crystallization is not possible.

Governments of the developed countries have tried to increase the pressure on the largest waste producers in order to reduce the undesired environmental pollution. For example, the Commission of the European Communities introduced the Integral Pollution and Prevention Control Directive (Council Directive, 1996). The purpose of the directive is to achieve integrated prevention and the control of pollution arising from the particular activities listed in its Annex I. Among others, the directive defines the Best Available Techniques (BAT) as the most effective and advanced stage in the development of activities and their operation methods which indicate the practical suitability of particular techniques for providing in principle the basis for emission limit values designed to prevent and, where that is not practicable, generally to reduce emissions and the impact on the environment. The European IPPC Bureau published a relevant document (BREF) where the BAT for the Food, Drink and Milk Industry are presented (IPPC, 2003). To a larger extent, the general techniques commonly used in this industry are described. However, no BAT is described relating specially to sugar beet production. Detailed information can be found in chapter 4, under the title Techniques to Consider in the Determination of BAT. The chapter contains a list of various pollution prevention, waste minimization and energy efficiency techniques applied in industry that are described everywhere, e.g. in books, journals, leaflets, the internet, etc. Recent research in the sugar industry has been focused on the development and implementation of new technologies and/or the particular unit operations, which would replace the traditional ones. The separation operation deserves special attention because of its significant consumption of water end energy.

Up to now, very few large-scale membrane separation processes have been applied in the sugar industry worldwide despite the encouraging results of numerous investigations published in the literature (Kwok, 1996; Willet, 1997; Chou, 2002; Lipnizki et al., 2006). In principle, all the separations in sugar production from beet or cane juices could be performed with appropriate membrane separation processes. In practice, however, regarding the high capacities of the sugar factories and relatively low price of sugar, the investment in an imaginary factory, operating exclusively with membranes or with other new environmentally friendly separation methods, would still be to high. The other approach is to find those membrane separation processes which could be advantageously embedded into or combined with the traditional technology to increase the effectiveness of the sugar production as a whole. This latter concept is closer to the actual state of the industry. 


\section{Membrane Separation Processes}

\subsection{Introductory Comments}

Membrane separation is a pressure driven filtration technique in which a solution is forced through a porous membrane. Some of the dissolved solids are held back because their molecular size is too large to allow them to pass through. The size range depends upon the type of membranes used. Fractionation of the feed stream occurs, with some molecules being concentrated on the upstream side of the membrane, which is known as the concentrate or retentate. The smaller molecules pass through the membrane into the permeate stream. The variety of membrane separation techniques can be characterized by their membrane pore size.

Cross-flow microfiltration (MF) membranes can be used to remove non-sucrose compounds, or to fractionate the retentate rich in colourants. Ultrafiltration (UF) membranes can be applied to concentrate the relevant juices in sugar industry and to remove non-sucrose compounds. This membrane pore size ranges from about 10 to $100 \mathrm{~nm}$. Applications of UF can be extended to the removal of oil from waste water and the removal of turbidity and colour colloids from juices. Nanofiltration (NF) membranes have selective permeability for minerals and some small organic and inorganic molecules and NF is used predominantly for concentration and pre-demineralization (removal of salts) of juices and waste water in sugar industry; the pore size of the NF membrane ranges from about 1 to $10 \mathrm{~nm}$. Reverse osmosis filtration (RO) membranes are permeable to water but not minerals and are therefore used for dewatering and for removing heavy metals and pesticides. They are also used for refinement of NF permeates or evaporator condensate as well as in water treatment, such as softening and salt removal; this membrane pore size ranges from about 0.1 to $1 \mathrm{~nm}$ (Cheryan, 1986). Membranes can also be classified according to the material used for their production. So, polymeric, inorganic - ceramic and metallic- membranes are well known.

Along with the membrane characteristics, operating conditions are also significant. Among possible regimes, cross flow filtration has proven the best. Also important are following independent variables: transmembrane pressure, flow rate of the liquid phase, its temperature and process duration. Their optimization is a difficult task which can be performed either empirically or by solving adequate mathematical models. Certain number of papers is dealing with the mathematical modelling of the process, based on theoretical background as well as on statistical processing the measured data. As for the required goal, the quality of permeate, expressed through its colour, purity, turbidity, etc., is given the priority.

Sugar has to satisfy rigorous quality demands; particularly important are demands related to the colour of its crystals. Ensuring colour quality parameters of white sugar (EU-1 and EU-2) used to be difficult especially when the quality of the processed beet is poor (Šereš et al., 2004; Gyura et al., 2004). The limits of the traditional purification operations are well known; by using purification with lime, only $35 \%$ of non-sucrose compounds can be removed. Also, assurance of colour quality is expensive due to the high energy consumption of the sugar house: heat and electricity, or even if enough energy could be provided, limited capacities of equipment in the sugar house might cause stresses in the operation of the factory. In such a situation it seems reasonable to look for an additional non-sucrose compound elimination method by which the required colour, to obtain EU-2 white sugar from the standard liquor (feed of the 1st evaporating crystallizer) can be provided. 
In the membrane separation technique water is used periodically to clean the separation equipment. The frequency of cleaning and the volume of water used vary depending on the product and equipment. Waste water from washing as well as from the process itself (in the form of separated waste products) contains dissolved non-sucrose compounds. Membrane separation as a pressure driven process requires electrical energy. The achieved environmental benefits are as follows: reduction of levels of the suspended, colloidal and dissolved solids in water, reduction of phosphorus levels and collection of waste water streams, thus reducing their volume prior to further possible treatment (IPPC, 2003). Also, it is possible to recover the expensive ingredients for re-use as well as to recover water for reuse. Problems may arise from the fouling of membranes and gel polarization. Since the flux rates through membranes are relatively low, an extensive membrane area is required.

\subsection{Short History of Investigations}

Investigations of membrane separation processes have started through their combinations with the traditional processes. It was already mentioned, the traditional raw juice purification involves non-sugars precipitation with lime. Surplus $\mathrm{Ca}(\mathrm{OH})_{2}$ is eliminated by the $\mathrm{CO}_{2}$ gas. Sludge produced is then filtrated through filters and pressed in the filter presses. Not only waste is produced in this process but an additional lime production plant would be needed, where solid waste (stones, sand, etc.), wastewater and waste gasses are produced. Urbaniec (Urbaniec et al., 2000) proposed an alternative process instead. Raw juice purification by the lime is replaced by screening and micro-filtration followed by low temperature evaporation. It is also well known that the conventional concentration of thin juice by evaporation requires about $50 \%$ of the total energy. In order to decrease this amount, nanofiltration and reverse osmosis has been considered as pre-concentration step before evaporation (Cartier et al, 1997; Gosh et al., 2000; Gosh \& Balakrishnan, 2003). An overall concept for treatment or raw juice with polymeric hollow fiber microfiltration is the A.B.C. process which combines a continuous screening with ultrafiltration followed by softening and alkaline adjustment before evaporation and adsorption (Wilett, 1997). Madsen, Nielsen and Attridge studied the raw beet juice purification by ultrafiltration and microfiltration (Madsen, 1973; Nielsen et al., 1982; Attridge et al., 2001) using polymeric membranes. Apart from using polymeric membranes, the use of inorganic - ceramic and metallic- membranes to achieve commercially interesting fluxes and permeate purities has been investigated. Hinkova et al. (Hinkova et al., 2002) observed that the filtration of diluted raw juice concentrate with ceramic membrane led, at a pilot scale, to a significant decrease in colloids and colour matters resulting in juice suitable for direct crystallization. Schrevel (Schrevel, 2002) compared the results obtained on different membranes in different module configurations. He concluded that supplementary treatments of the beet juice, such as prefiltration and pre-liming with carbonation, aid the ultrafiltration and guarantee the required sugar quality. Tebble et al. (Tebble et al., 2002) have proposed the integration of membranes, in a side stream approach, to reduce the need for lime and to boost the overall capacity of the raw juice purification. Kochering et al. (Kochering et al., 2003) have combined microfiltration and ultrafiltration for lime free raw juice purification using an ion exclusion process. Here membrane filtration is used after a clarifier and followed by softening, evaporation and chromatography for the elimination of non-sucrose and colour. The result is high quality of white sugar. Koekoek et al. (Koekoek et al., 1998) tested nanofiltration spiral wound and tubular modules for the concentration of thin juice. In spite of the 
acceptable fluxes at the beginning of the process, the long term performance of the membranes was disappointing due to fouling. Cleaning could not restore the initial fluxes. Similar results were obtained by Hinkova et al. (Hinkova et al., 2002). Beside application of membrane separation processes in sugar juice purification, there where attempts to use reverse osmosis to recycle pulp press water (Bogliolo et al., 1996) or to recover pectin from sugar beet pulp (Hatziantoniou \& Howell, 2002).

Our early investigations on membrane separation of sugar-beet juices has started with the experiments on polymeric membranes (Eszterle et al., 2000; Gyura et al., 2001; Gyura et al., 2002a; Gyura et al., 2002b; Eszterle et al., 2003) at temperatures whose limit was $60{ }^{\circ} \mathrm{C}$, according to the physical characteristics of the applied polymer materials (polyethersulfone and polyamide). Further investigations were performed on ceramic membranes which allow ultrafiltration of sugar juices at $80{ }^{\circ} \mathrm{C}$. In this way, a simulation of real process was possible. At the same time, a turbulence promoter was introduced and the efficiencies of processes, without and with the application of static mixer, were compared (Šereš et al., 2005, Šereš et al., 2006a; Šereš et al., 2006b). Analysis of working conditions as significantly important factors in ultrafiltration and nanofiltration processes were investigated at a laboratory level and the obtained results were used for suggesting optimal conditions (Gyura et al., 2004; Djurić et al., 2004; Gyura et al., 2005). The suggestions mostly rely on the analysis of experimental values, but some of them suggested optimal solutions by using adequate mathematical models. Djurić et al. (Djurić et al., 2004) proposed the flux models as functions of concentration factor, flow rate, temperature and transmembrane pressure as independent variables. The suggested mathematical model enables prediction of separation time if the permeate fluxes as well as the initial and final concentrations of undesired nonsucrose compounds are known.

Similar to the research related to the purification of raw beet juice, the use of microfiltration and ultrafiltration for the purification of cane juices was investigated (Hamachi et al., 2003, Martoyo et al., 2000). Experiences acquired through these investigations might be of broader importance and will be presented shortly. In 1994, the first New Applexion Process was installed in a cane sugar factory (Kwok, 1996). The ultrafiltration stage was designed to treat $380 \mathrm{~L} / \mathrm{min}$ of pre-filtered limed clear juice after the clarifier. A modification of the above mentioned process was developed by Chou (Chou, 2002). Also the A.B.C. process has been adopted for cane juice purification (Willet, 1997). Martoyo (Martoyo et al., 2000) described the successful application of spiral wound ultrafiltration elements for the prefiltered/screened raw juice with fluxes in economically interesting range (up to $120 \mathrm{~L} / \mathrm{m}^{2} \mathrm{~h}$ ). The applicability of spiral wound modules was approved by pilot tests but with lower fluxes (Gosh et al., 2000; Gosh \& Balakrishnan, 2003). More recently, membrane distillation became one of the latest technologies introduced to cane industry. By this process two streams with different temperatures are separated through a non-wetted microporous membrane. The driving force of the mass transfer is the vapour pressure difference resulting from the temperature gradient across the membrane (Nene et al., 2002). Despite purification steps before the concentration, cane sugar juice still contains high-molecular mass components. Microfiltration and ultrafiltration have been proposed as decolourization and purification methods. Dornier et al. (Dornier et al., 1995) focused their investigations on the performance of tubular ceramic microfiltration membranes. Cartier (Cartier et al., 1996a and 1996b) studied the influence of flocculation which preceded the microfiltration and ultrafiltration with tubular membrane. The most promising was the $300 \mathrm{kDa}$ membrane allowing fluxes of $65 \mathrm{~L} / \mathrm{m}^{2} \mathrm{~h}$. The decolourization rate was $50 \%$ while the removal of 
turbidity was 90\%. Decloux et al. (Decloux et al., 2000) concluded that ceramic membrane with $15 \mathrm{kDa}$ has the best decolourization rate at $60{ }^{\circ} \mathrm{C}$. In 2003, Hamachi and co-authors highlighted the limitations of using ultrafiltration for decolourization (Hamachi et al., 2003). It was found that even with membranes of $1 \mathrm{kDa}$ colour removal would not exceed $60 \%$ while the flux decreased below $30 \mathrm{~L} / \mathrm{m}^{2} \mathrm{~h}$. Key success factors for an efficient application are both pre-treatment and operating conditions (Lipnizki et al., 2006).

\subsection{New Trends}

The commercial application of ultrafiltration, for the separation of non-sucrose compounds, is limited because of the concentration polarization and progressive fouling of the membrane. It can be expected that the molar mass of colourants increases while the density of sugar juice increases due to the polycondensation reactions favored at low water contents. According to the gel chromatography measurements (Anyos, 1984; Godshall et al., 2002), approximately $35 \%$ of all colourants, present in the initial sugar juice, have the molar mass higher than $4000 \mathrm{~g} / \mathrm{mol}$, while $51 \%$ and $81 \%$ of colourants, with the mentioned molar mass, are present in solution of the 2 nd and the 3 rd sugar. It can be concluded that elimination of colourants by ultrafiltration would be more efficient in the case of the raw sugar solutions of the 2 nd or 3rd crystallization then in the case of the thick juice. The second important reason for applying ultrafiltration on thin juices might be the smaller quantity of these juices compared to the thick juice. Namely, the required membrane surface is proportional to the quantity of treated solution. In the industrial application permeate is to be sent to the 1st stage of crystallization and the darker coloured retentate into the 3rd stage of crystallization.

The described phenomena cause decline in permeate flux during the ultrafiltration of sugar juice. To make membrane separation process practically applicable, permeate flux should be increased. Among all the hydrodynamic methods used for improving mass transfer in cross flow membrane filtration, an increase in cross flow velocity represents the simplest way to create turbulence and reduce membrane fouling. Such an increase in cross flow velocity and thus enhanced permeate fluxes has been obtained by applying static turbulence promoters with or without superimposing pulsations for creating unsteady flow (Krstić et al., 2006). Kenics static mixers are the most common static mixers applied in the industry. Some studies on the use of Kenics static mixers, as turbulence promoters in cross flow membrane process, have been reported in the literature (Šereš et al., 2006a). A significant decrease of a gel layer concentration at the membrane surface has been observed (Vatai \& Tekić, 1995). On the other hand, increased power consumption for fluid flow was required because of the increase of pressure drop along the membrane module with inserted static mixer. Most of these techniques are applied to ceramic membranes.

Only a few investigations were reported on the problem of ultrafiltration of sugar juice in the presence of static mixer as turbulence promoter (Šereš et al., 2005; Šereš et al., 2006a; Šereš et al., 2006b). We will present some results (at laboratory level) related to the removing undesired molecules from the sugar juice by the use of ceramic membranes, with and without presence of static mixer, under various working conditions. The process efficiency is quantified through the achieved values of permeate flux and its colour, while the working factors were: fluid flow rate, temperature, trans-membrane pressure and process duration. As treated raw sugar syrup (ca. $60 \%$ dry substance) belongs to viscous fluids, static mixer was expected to improve the permeate flux as well as the separation process as a whole. 


\section{Material and Methods}

Non-affinated sugar from the 2nd stage of crystallization, diluted to 60 ०Bx of dry matter, was used as material for the investigation of coloured matter separation by UF and for examining the influence of static mixer on the separation process. Its basic characteristics corresponded to regular technological quality (Reinefeld \& Schneider, 1978); its colour was 1957 and its purity was $98.51 \%$.

The laboratory UF equipment was set up at the Faculty of Food Industry, "Corvinus" University in Budapest. The flow diagram of the setup is shown in Fig. 1.

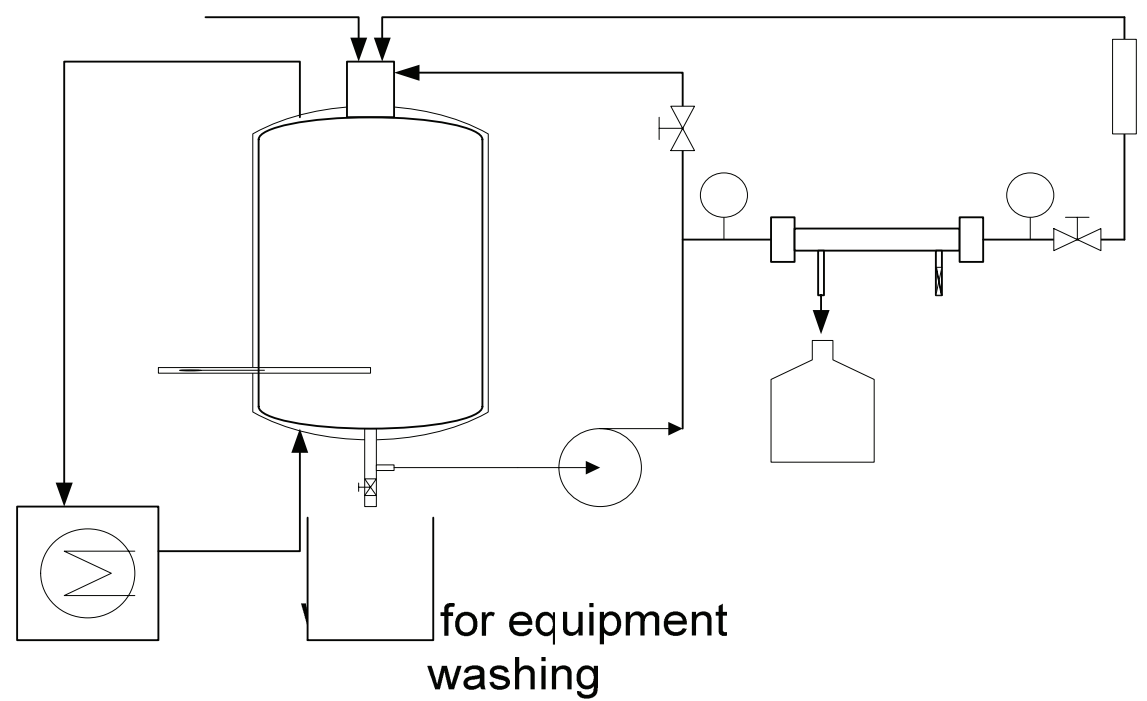

Fig. 1. Laboratory setup for ultrafiltration: 1 - feed tank, 2 - thermostat, 3 - pump $(0.25 \mathrm{~kW})$, 4 - module with membrane, 5 - vessel for permeate, 6 - vessel for retentate, 7, 8, 9 valves, 10 - thermometer, 11, 12 - manometer, 13 - rotameter

The cross-flow filtration was realized on the membrane of $20 \mathrm{~nm}$ pore diameter (Membralox ceramic tubular membrane, SCT, Bazet, France), made of a zirconium oxide layer on an aluminum oxide support. The membrane was a single channel type $250 \mathrm{~mm}$ long, with 6.8 $\mathrm{mm}$ inner diameter. The useful membrane surface was $4.62 \times 10^{-3} \mathrm{~m}^{2}$. The effect of turbulence promotion on filtration performances was investigated by using Kenics static mixer (FMX8124-AC, Omega), consisting of 30 elements and having aspect ratio (length to diameter) of 1.

Experiments were performed in accordance with the plan presented in Table 1, where the lower and the upper boundaries of the independent variables are given. Experiments were performed without and with the application of static mixer, i.e. in non-static mixer mode (NSM- mode) and in static mixer mode (SM- mode). 


\begin{tabular}{lllll}
\hline $\begin{array}{l}\text { Independent } \\
\text { variables }\end{array}$ & NSM- mode & \multicolumn{3}{l}{ SM- mode } \\
\cline { 2 - 5 } & $\begin{array}{l}\text { Lower } \\
\text { level }\end{array}$ & $\begin{array}{l}\text { Upper } \\
\text { level }\end{array}$ & $\begin{array}{l}\text { Lower } \\
\text { level }\end{array}$ & $\begin{array}{l}\text { Upper } \\
\text { level }\end{array}$ \\
\hline Q, L h-1 & 150 & 400 & 50 & 400 \\
$\mathrm{t},{ }^{\circ} \mathrm{C}$ & 70 & 80 & 70 & 80 \\
$\mathrm{P}, \mathrm{bar}$ & 6 & 10 & 3 & 10 \\
$\tau, \mathrm{h}$ & 0 & 2 & 0 & 2 \\
\hline
\end{tabular}

Table 1. Plan of experiments - boundaries of independent variables

A full factorial design was applied and flow rate $(\mathrm{Q})$, temperature $(\mathrm{t})$ and trans-membrane pressure $(P)$ were kept at two levels, while time $(\tau)$ was continually measured together with the measurements of two dependent variables: permeate flux and colour change. The permeate colour change is expressed as a difference between the colours of the permeate and juice, divided by the colour of the initial juice. The colour is quantified by the absorbance, measured on a spectrophotometer at $420 \mathrm{~nm}$. As for the reproducibility of the results only those measurements were repeated (more than two times) which gave significantly different values when twice repeated.

\section{Results and Discussion}

The results of the investigations are presented in Figs. 2-8. The experimental values of the presented variables were taken at the beginning and at the end of ultrafiltration process, after $0.5 \mathrm{~h}$ and after $2 \mathrm{~h}$. In this way, the process could be analyzed in real time and more accurate conclusions could be drawn. From the Fig. 2, it can be seen that the greatest flux, through the ceramic membrane without static mixer, could be reached at temperature of $80^{\circ} \mathrm{C}$, flow rate $400 \mathrm{~L} \mathrm{~h}^{-1}$ and pressure of $10 \mathrm{bar}$, after $0.5 \mathrm{~h}$ of ultrafiltration. It can also be seen that the best flux through the membrane supplied by static mixer could be reached under the same conditions. Also, when the pressure was held at $6-10$ bar and when the flow rate was lower than $100 \mathrm{~L} \mathrm{~h}^{-1}$, permeate flux (in SM-mode of operation) got high value. Comparison of fluxes typical of NSM- and SM- mode of operation, at the beginning of process, did not show significant difference. In Fig. 3, fluxes at the end of ultrafiltration process were presented. Trends similar to those at the beginning were noticed, but after $2 \mathrm{~h}$ lower absolute values of fluxes were achieved in both modes. However, it could be concluded that about $30 \%$ higher flux was reached in the presence of static mixer, at lower transmembrane pressure, which is important for energy saving. Flux values measured at $70^{\circ} \mathrm{C}$, which were not graphically presented due to limited space, were higher in SM-mode of operation as follows: i) $50 \%$ after $0.5 \mathrm{~h}$, ii) $60 \%$ after $1 \mathrm{~h}$ and iii) $65 \%$ after $2 \mathrm{~h}$. As expected, static mixer has great effect on ultrafiltration of juice with higher viscosity. 

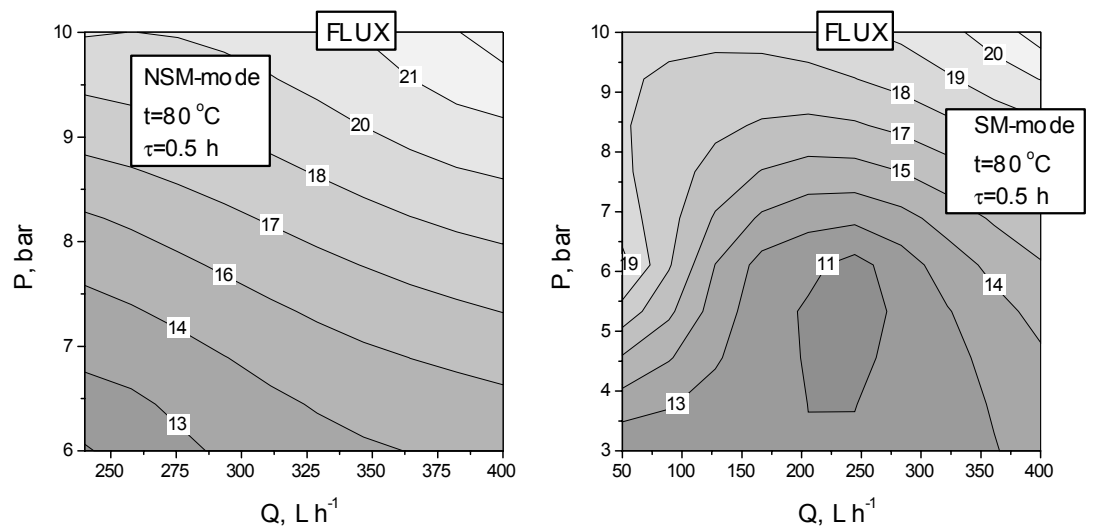

Fig. 2. Permeate flux as a function of flow rate and transmembrane pressure at $0.5 \mathrm{~h}$ of ultrafiltration
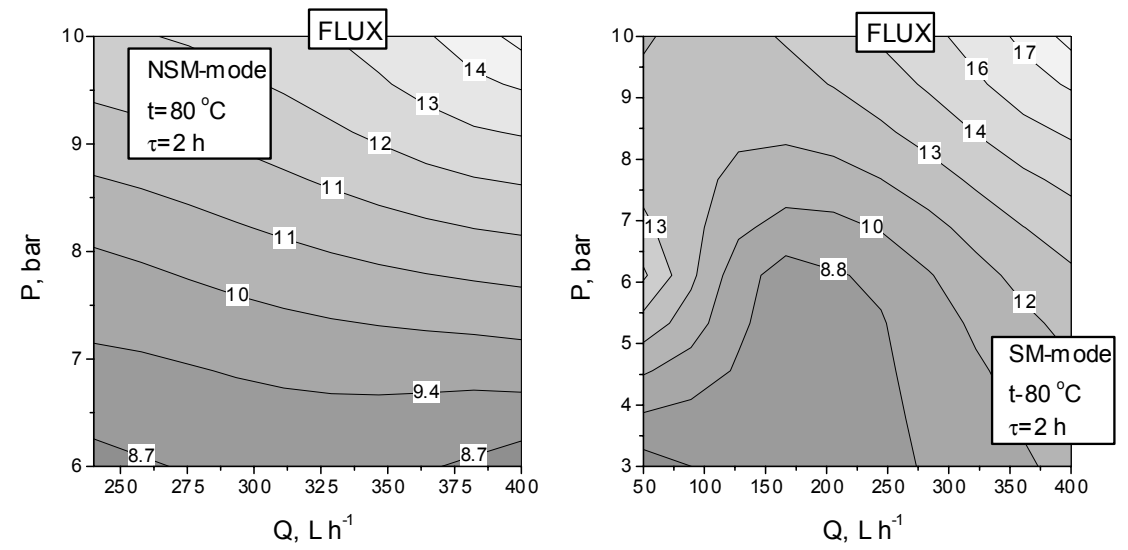

Fig. 3. Permeate flux as a function of flow rate and transmembrane pressure at $2 \mathrm{~h}$ of ultrafiltration

By ultrafiltration, in the presence of ceramic membrane with pore size of $20 \mathrm{~nm}$ without static mixer, permeate colour decreased approximately 35\% - 40\% (see Figs. 4 and 5). These values could be reached at NSM- mode, while pressure was held at 6 bar and flow rate has value lower than $250 \mathrm{~L} \mathrm{~h}^{-1}$. However, in the presence of static mixer, following reduction of colour matter could be achieved: i) $45 \%$ after $0.5 \mathrm{~h}$ of ultrafiltration and ii) $60 \%$ after $2 \mathrm{~h}$ of ultrafiltration. Optimal working conditions are: flow rate between $100-200 \mathrm{~L} \mathrm{~h}^{-1}$ and pressure above 6 bar (see Figs. 4 and 5). Obviously, when a static mixer was used the decolourization of permeate was highly efficient. Comparison between NSM-mode and SMmode of operation leads to a conclusion that SM-mode gives greater effects, $30 \%$ after $0.5 \mathrm{~h}$ and $55 \%$ after $2 \mathrm{~h}$. 

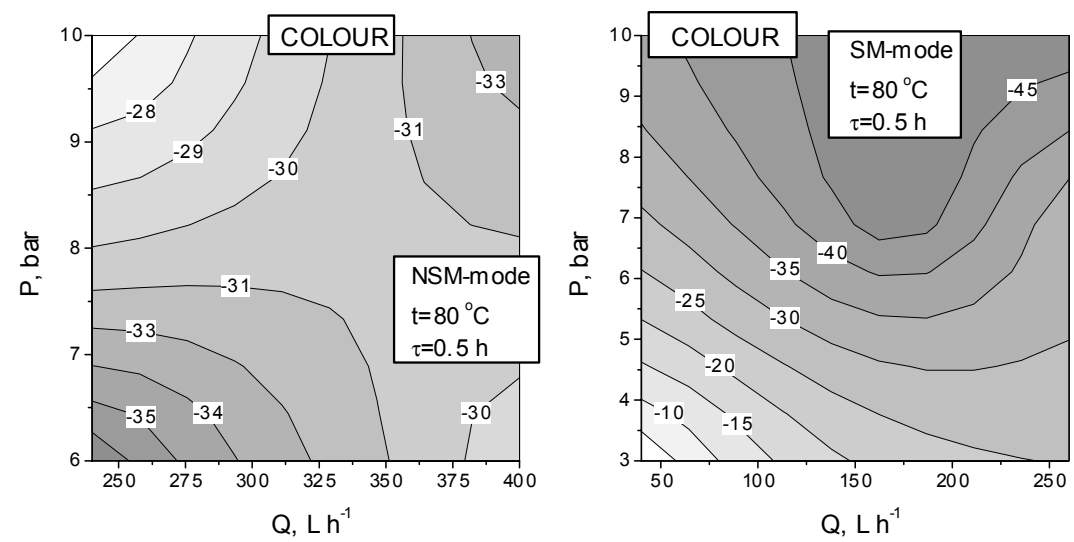

Fig. 4. Permeate colour as a function of flow rate and transmembrane pressure at $0.5 \mathrm{~h}$ of ultrafiltration
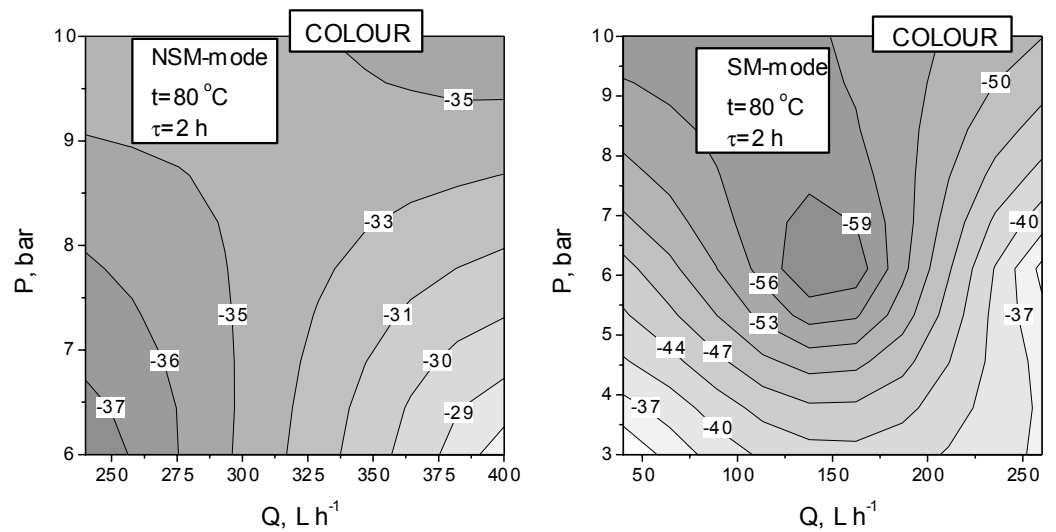

Fig. 5. Permeate colour as a function of flow rate and transmembrane pressure at $2 \mathrm{~h}$ of ultrafiltration

Analysis of the diagram in Fig. 6. showed that the juice colour decreased from 1080 IU to $750 \mathrm{IU}$. On the other hand, the retentate colour increased up to $1200 \mathrm{IU}$. At the same time, the permeate purity (defined as a ratio obtained by dividing the measured values of sucrose and quantity of dry matter content) increased from $98.9 \%$ to $99.7 \%$, while the retentate purity decreased from 98.9 to $97 \%$. Such a change of purity shows that membrane with 20 $\mathrm{nm}$ pore sizes does not reject sucrose molecules and there is no change in permeate dry matter content (because the main part of dry matter is sucrose). 


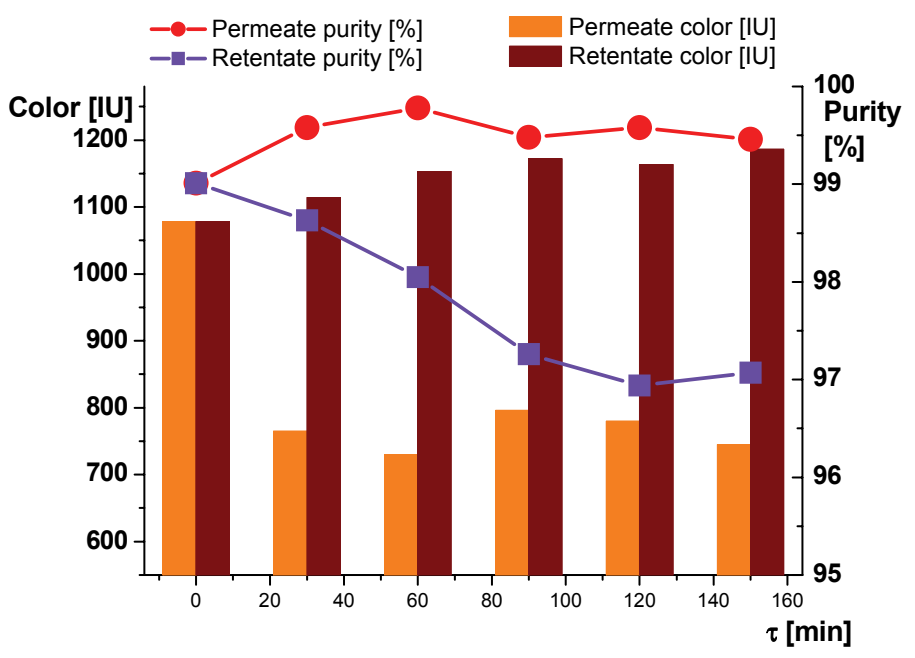

Fig. 6. Colour and purity of permeate and retentate in NSM- mode at flow rate $400 \mathrm{~L} / \mathrm{h}$, pressure at 6 bar and temperature at $80^{\circ} \mathrm{C}$

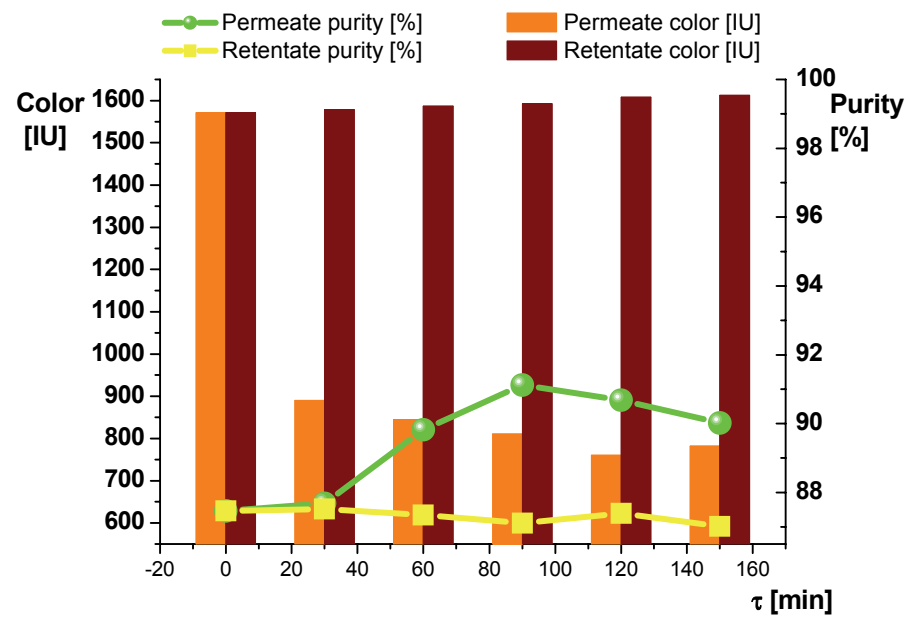

Fig. 7. Colour and purity of permeate and retentate in SM- mode at flow rate $400 \mathrm{~L} / \mathrm{h}$, pressure at 6 bar and temperature at $80^{\circ} \mathrm{C}$

When static mixer was used, the decolourization of permeate was more efficient (see Fig. 7.). The permeate colour decreased for about $50 \%$ while its purity increased for $2 \%$.

The difference between pressures at opposite sides of the UF- module, as a function of average working pressure, is shown in the case of SM- mode of operation at $80^{\circ} \mathrm{C}$ in Fig. 8. It is interesting to observe that an increase of flow rate from 25 to $400 \mathrm{~L} \mathrm{~h}^{-1}$ causes an increase 
of the pressure difference from 0.1 to 3.7 bar. It could be concluded that flow rate has significant influence on the ultrafiltration when static mixer is used. High pressure drop along the length of the membrane (Fig. 8.) and therefore the increase in energy consumption per unit volume of permeate (E) is usually the main disadvantage of configurations with static turbulent promoters.

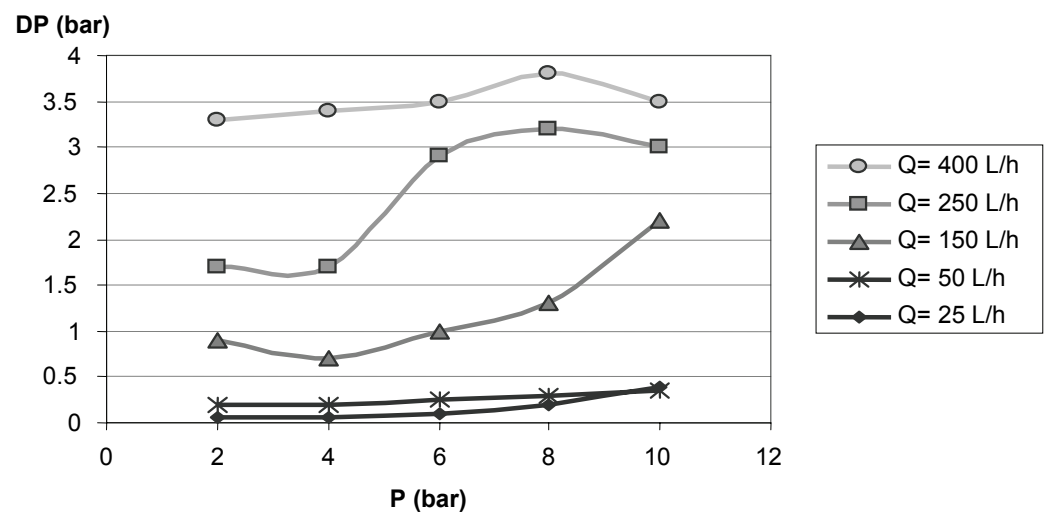

Fig. 8. Pressure drop along the length of the membrane (measured before and after UF module) as a function of the applied pressure in SM- mode at $80^{\circ} \mathrm{C}$

The loss of hydraulic pressure (HP), due to the pressure drop along the length of the membrane in the SM-mode and NSM-mode of operation, is presented in Table 2. It is obtained by multiplying the pressure drop along the length of the membrane to the liquid velocity. As it is obvious, the loss of hydraulic pressure is much greater in the ultrafiltration process performed without static mixer compared to the process with the mixer at the same flux values. Namely, when static mixer is used higher fluxes can be achieved at lower velocities. At lower velocity, the pressure drop has also lower value. When the permeate flux increases the loss of hydraulic pressure in NSM- mode and SM- mode become similar. The results of an analysis of energy consumption per unit volume of permeate (E), in both modes of operation, are presented in Table 2 as well. Finally, the energy reduction (ER) for the sake of using static mixer is given. As it is obvious from Table 2, energy reduction is proportional to the permeate flux values (the greater the flux the higher the energy reduction). Under the investigated conditions, the energy reduction in SM- mode of operation reached approximately $85 \%$ comparing to NSM- mode.

\begin{tabular}{|l|l|l|l|l|l|}
\hline \multirow{2}{*}{$\mathrm{J}\left[\mathrm{L} / \mathrm{m}^{2} \mathrm{~h}\right]$} & \multicolumn{3}{|l|}{$\mathrm{HP}[\mathrm{W}]$} & $\mathrm{E}\left[\mathrm{kWh} / \mathrm{m}^{3}\right]$ & \multirow{2}{*}{ ER [\%] } \\
\cline { 2 - 5 } & $\mathrm{SM}$ & $\mathrm{NSM}$ & $\mathrm{SM}$ & $\mathrm{NSM}$ & \\
\hline 8 & 0,21 & 0,56 & 5,68 & 15,15 & 62,51 \\
\hline 16 & 0,28 & 1,25 & 3,79 & 16,91 & 77,58 \\
\hline 20 & 0,42 & 2,70 & 4,55 & 29,22 & 84,43 \\
\hline
\end{tabular}

Table 2. Loss of hydraulic pressure due to the pressure drop along the length of the membrane (HP), energy consumption per unit volume of permeate (E) and energy reduction due to the presence of static mixer (ER) 


\section{Conclusion}

The data collected on the impact of the traditional sugar beet processing on the environment pollution have shown that the greatest disadvantage is related to very high amount of required energy (mostly for the evaporation). The second important disadvantage is associated with the high level of water consumption (mostly for the extraction). The third disadvantage is connected to the purification of sugar juice and removal of non-sucrose compounds, undesired from the point of view of sugar quality. This chapter is related to the third disadvantage, which can be avoided or at least decreased by introducing environmentally friendly operation- membrane separation, instead of traditional operationpurification by chemically induced precipitation of undesired macromolecules.

Membrane separation is applied in food and chemical industry for several decades but its application in purification of sugar juices is still under investigations. Aware of the fact that membrane separations have great potential, many scientists are dealing with their adjustment to the requirements of sugar-industry. This chapter offers a review of results on the purification of sugar- beet juices and sugar- cane juices by membrane separations, mostly at a laboratory level. Despite the encouraging character of these results, very few large-scale membrane separation processes have been applied in the sugar industry worldwide. The reason lies in the fact that some weaknesses of the membrane separation processes have to be reduced before the separation can be applied on a large-scale. One of the greatest weaknesses is a gradual decrease of permeate flux through membrane caused by the precipitation of rejected macromolecules on the membrane surface. Among all the hydrodynamic methods used for improving mass transfer in membrane filtration, an increase in flow velocity represents the simplest way to create turbulence and reduce membrane fouling. Such an increase can be obtained by applying static turbulence promoters- static mixers. Some of our results on static mixer application together with the results on the same system without mixer application are presented comparatively. It is concluded that this kind of improvement makes membrane separation process closer to its industrial application which is highly desired from the point of view of environment protection.

\section{Acknowledgment}

These investigations are part of the project No. 142045, supported by the Ministry of Science, Serbia.

\section{References}

Anyos, E. (1984). Clarification of sugar-house products by liming and carbonatation, Thesis, Budapest

Attrige, L.; Erings, A. \& Jaferey, I. (2001). Ultrafiltration of beet diffusion juice using spiral and tubular polymeric membranes, ASSBT 2001, Proceedings of 3rd General meeting, pp. Vancouver, 2001

Bogliolo, M.; Bottino, A.; Capanelli, G.; De Petro, M.; Servida, A.; Peyyi, G. \& Vallini, G. (1996). Clean water recicle in sugar extraction process: performance analysis of reverse osmosis in treatment of press water. Desalination, Vol. 108, 261-271, 00119164 
Cartier, S.; Theoleyre, M.A. \& Decloux, M. (1996a). Combination of flocculation and crossflow filtration for removing colored impurities in raw cane sugar solutions. Proceedings of the 1996 S:P:R:I. workshop on separation processes in the sugar industry, New Orleans, USA, April 14-17, Sugar Processing Research Institute inc. (spri), www.spriinc.org

Cartier, S.; Theoleyre, M.A.; Lancrenon, X. \& Decloux, M. (1996b). Membranes Technology in the Sugar Industry. Proceedings of the 1996 S:P:R:I. workshop on separation processes in the sugar industry, New Orleans, USA, April 14-17, Sugar Processing Research Institute inc., (spri), pp. 55, www.spriinc.org

Cartier, S.; Tatoud, L.; Theoleyre, M.A. \& Decloux, M. (1997). Sugar refining process by coupling flocculation and crossflow filtration. Journal of Food Engineering, Vol. 32, 155-166, 0260-8774

Cheryan, M. (1986). Ultrafiltration Handbook, Technomic Publishing Co. Inc., 87762-456-9, Lancaster, Basel

Chou, C.C. (2002). White and refind sugar production from cane sugar factories. Proceedings of First Biennial World Conference on Recent Developments in Sugar Technologies, pp. 5, Delray Beach, Florida USA, May 2002, Dr. Chou Technologies, Inc. New York, USA and South China University of Technology, Guangzhou, China, www.esugartech.com

Council Directive 96/61/EC. (1996). Concerning Integrated Pollution Prevention and Control, Official Journal of the European Communities, No. L 257/26, 10.10.1996.

Decloux, M. \& Tatoud, L. (2000). Importance of the control mode in ultrafiltration: case of raw sugar remelt. Journal of Food Engineering, Vol. 44, 119-126, 0260-8774

Djurić, M.; Gyura, J.; Zavargo, Z.; Šereš, Z. \& Tekić, M. (2004). Modelling of ultrafiltration of non-sucrose compounds in sugar beet processing. Journal of Food Engineering, Vol. 65, 73-82, 0260-8774

Dornier, M.; Petermann, R. \& Decloux M. (1995). Influence of start-up procedure on crossflow microfiltration of raw cane sugar. Journal of Food Engineering, Vol. 24, 213224, 0260-8774

Eszterle, M., Šereš, Z. \& Vatai, Gy. (2003). Elimination of colouring substances from sugar factory syrups by ultra- and nano-filtration. Proceedings of International Conference of Visegrad Countries, Permea, pp. 69, Tatranska Matliare, Slovakia, September 2003, Slovak Society of Chemical Engineering, Slovak University of Technology, CDROM

Eszterle, M.; Šereš, Z.; Vatai, Gy. \& Gyura, J. (2000). Elimination of colouring substances from sugar industrial solution by ultrafiltration. Proceedings of the XI International Conference of Membrane Techniques, pp. 16-17, ISBN 963820397 8, Tata, Hungary, October 2001, Múszaki és Természettudományi Egyesületek Szövetsége, Tatabánya

Godshall, M.A.; Vercelotti, J. \& Triche, R. (2002). Effect of Macromolecules on Sugar processing: Comparition of Cane and Beet Macromolecules. Proceedings of 9th Symposium AVH Association, pp. 23-30, Reims, France

Gosh, A.M.; Balakrishnan, M.; Dua, M. \& Bhagat, J.J. (2000). Ultrafiltration of sugarcane juice with spiral wound modules: on-site pilot trials. Journal of Membrane Science, Vol. 74, 205-216, 0376-7388 
Gosh, A. M. \& Balakrishnan M. (2003). Pilot demonstration of sugarcane juice ultrafiltration in an Indian sugar factory. Journal of Food Engineering. Vol. 58, 143-150, 0260-8774

Gyura, J.; Šereš, Z. \& Eszterle, M. (2001). Effects of ultra- and nano-filtration on separation of non-sucrose compounds in sugar industry syrup. Proceeding of 17th International Congress of Nutrition, pp. 370, ISBN 3-8055 7294-8, Vienna, Austria, August 2001, Karger Medical and Scientific Publishers, Basel

Gyura, J.; Šereš, Z.; Vatai, Gy. \& Békási-Molnár, E. (2002a). Separation of non-sucrose compounds from the syrup of sugar beet processing by ultra- and nanofiltration using polymer membranes, Desalination, Vol. 148, 49-56, 0011-9164

Gyura, J.; Šereš, Z. \& Békási-Molnár, E. (2002b). Separation of nonsucrose compounds from the syrup of sugar-beet by ultrafiltration and nanofiltration. Proceeding of International Congress on Membranes and Membrane Processes, pp. 432, Toulouse, France, July 2002, Europian Comission, Paris

Gyura, J.; Šereš, Z. \& Eszterle, M. (2004). Influence of operating parameters on the separation of colorants from sugar house juices by ultra- and nanofiltration. Zuckerindustrie , Vol. 129, 174-180, 0344-8657

Gyura, J.; Šereš, Z. \& Eszterle, M. (2005). Influence of operating parameters on separation of green syrup colored matter from sugar beet by ultra- and nanofiltration. Journal of Food Engineering, Vol. 66, 89-96, 0260-8774

Hamachi, M.; Gupta, B.B. \& Ben Aim, R. (2003). Ultrafiltration: a means for decolorization of cane sugar solution. Separation and Purification Technology, Vol. 30, 229-239, 13835866

Hatziantoniou, D. \& Howell, J.A. (2002). Influence of the properties and characteristics of sugar-beet pulp extract on its fouling and rejection behaviour during membrane filtration. Desalination, Vol. 148, 67-72, 0011-9164

Hinkova, A.; Bubnik, Z.; Kadlec, P. \& Pridal, J. (2002). Potentials of separation membranes in the sugar industry. Separation and Purification Technology, Vol. 26, 101-110, 13835866

Integrated Pollution Prevention And Control (2003). Draft Reference on Best Available Techniques in the Food, Drink and Milk Industry, European Commission, DirectorateGeneral JRC, Institute for Prospective Technological Studies, European IPPC Bureau, Seville, http://eippcb.jrc.es

Kochering, V.; Kearney, M.; Jacob, W. \& Pryor, T. (2003). Chromatografic purification of raw beet juice: A lime free technology. Zuckerindustrie, Vol. 128, 667-672, 0344-8657

Koekoek, P.J.W.; Vannispen, J. \& Vermuelen, D.P. (1998). Nanofiltration of thin juice for improvement of juice purification. Zuckerindustrie, Vol. 123, 122-126, 0344-8657

Krstić, D.; Koris, A. \& Tekić, M. (2006). Do static turbulence promoters have potential in cross-flow membrane filtration applications?. Desalination, Vol. 191, No. 1-3, 371375, 0011-9164

Kwok, R.J. (1996). Production of super VLC raw sugar in Hawaii. Experience with the new NAP ultrafiltration / softening process. International Sugar Journal, Vol. 98, 490-496, 0020-8841

Lipnizki, F.; Carter, M. \& Tragardh, G. (2006). Applications processes in the beet and cane sugar production. Zuckerindustrie, Vol. 131, No. 1, 29-38, 0344-8657

Madsen, R. F. (1973). Application of UF and RO to cane juice. International Sugar Journal, Vol. 75, 163-167, 0020-8841 
Martoyo, T.; Hino, M.; Nagase, H. \& Bachtiar, A. (2000). Pilot test on ultrafiltration of cane raw juice at the Indonesian plantation white Kedawoeng sugar factory. Zuckerindustrie, Vol. 125, 787-792, 0344-8657

Nene, S.; Kaur, S.; Sumod, K.; Joshi, B. \& Ragharavarao, K.S.M.S. (2002). Membrane distillation for the concentration of raw cane sugar syrup and membrane clarified sugarcane juice. Desalination, Vol. 147, 157-160, 0011-9164

Nielsen, W.K.; Kristensen, S. \& Madsen, R.F. (1982). Prospects and possibilities in application of membrane filtration systems within beet and cane sugar industry. Sugar Technology Reviews, Vol. 9, 59-117, 0081-9204

Reinefeld, E. \& Schneider, F. (1978). Analitische Betriebskontrolle der Zuckerindustrie (Teil B), Verlag Dr. Albert Bartens, Berlin, 978-3-87040-019-4

Schrevel, G. (2002). Separation of macromolecules in beet sugar processing. Zuckerindustrie , Vol. 127, 768-769, 0344-8657

Šereš, Z.; Gyura, J.; Eszterle, M. \& Vatai, Gy. (2004). Coloured matters removal from sugar beet industry syrup by ultra- and nano-filtration. Acta alimentaria, Vol. 33, No. 2, 119-127, 0139-3006

Šereš, Z.; Gyura, J.; Eszterle, M. \& Vatai, Gy. (2005). Separation of non-sucrose compounds from syrup as a part of the sugar-beet production process by ultrafiltration with ceramic membrane. Membrane Science and Technology Conference of Visegrad Group - Permea 2005, Polanica Zdroj, Poland, CD

Šereš, Z.; Gyura, J.; Eszterle, M. \& Djuric, M. (2006a). Separation of non-sucrose compounds from syrup as a part of the sugar-beet production process by ultrafiltration with ceramic membranes. European Journal of Food Engineering, Vol. 223, 829-636, 02608774

Šereš, Z.; Gyura, J.; Tekić, M. \& Jokić, A. (2006b). The influence of the kenics static mixer on raw sugar solution ultrafiltration, Book of Abstracts of International Workshop on Quality of Food and Beverages in the Frame of EU Standards, p. 36, Bucharest, Romania, February 2006, Balkan Environmental Association (B.EN.A.) and Romanian Academy of Agricultural and Forestry Sciences (AAFS), Bucharest

Tebble, I.; Nelson, R. \& Sargent D. (2002). The use of membrane filtration to reduce lime usage in purification. Zuckerindustrie, Vol. 127, No. 8, 600-603, 0344-8657

Urbaniec, K.; Zalewski, P. \& Zhu X. X. (2000). A Decomposition Approach for Retrofit Design of Energy Systems in the Sugar Industry. Applied Thermal Engineering, Vol. 20, No. 15-16, 1431-1442, 1359-4311

Poel, Van der, P.; Schiweck, H. \& Schwartz, T. (1998). Sugar Technology - Beet and Cane Sugar Manufacture, Verlag Dr. Albert Bartens, 978-3-87040-065-1, KG - Berlin

Vatai, Gy. \& Tekic, M. (1995). Convection promotion and gel formation in an ultrafiltration process. Chem. Eng. Comm., Vol. 132, 141-149

Willet, C.C. (1997). The A.B.C. process for the production of refined sugar from beets. International Sugar Journal, Vol. 99, 48-50, 0020-8841 


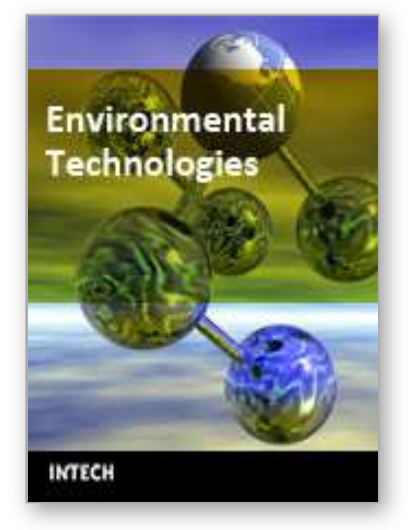

\author{
Environmental Technologies \\ Edited by E. Burcu Ozkaraova Gungor
}

ISBN 978-3-902613-10-3

Hard cover, 268 pages

Publisher I-Tech Education and Publishing

Published online 01, January, 2008

Published in print edition January, 2008

This book on Environmental Technology takes a look at issues such as air, soil and noise pollution problems, environmental quality assessment, monitoring, modelling and risk as- sessment, environmental health impact assessment, environmental management and envi- ronmental technology development. It represents institutional arrangements, financial mechanisms and some sustainable technologies. The user can always count on finding both introductory material and more specific material based on national interests and problems. The user will also find ample references at the end of each chapter, if additional information is required. For additional questions or comments the user is encouraged to contact the author.

\title{
How to reference
}

In order to correctly reference this scholarly work, feel free to copy and paste the following:

Zita Seres, Julianna Gyura, Mirjana Djuric, Gyula Vatai and Matild Eszterle (2008). The Application of Membrane Separation Processes as Environmental Friendly Methods in the Beet Sugar Production, Environmental Technologies, E. Burcu Ozkaraova Gungor (Ed.), ISBN: 978-3-902613-10-3, InTech, Available from:

http://www.intechopen.com/books/environmental_technologies/the_application_of_membrane_separation_pro cesses_as_environmental_friendly_methods_in_the_beet_sugar

\section{INTECH}

open science | open minds

\author{
InTech Europe \\ University Campus STeP Ri \\ Slavka Krautzeka 83/A \\ 51000 Rijeka, Croatia \\ Phone: +385 (51) 770447 \\ Fax: +385 (51) 686166 \\ www.intechopen.com
}

\author{
InTech China \\ Unit 405, Office Block, Hotel Equatorial Shanghai \\ No.65, Yan An Road (West), Shanghai, 200040, China \\ 中国上海市延安西路65号上海国际贵都大饭店办公楼405单元 \\ Phone: +86-21-62489820 \\ Fax: +86-21-62489821
}


(C) 2008 The Author(s). Licensee IntechOpen. This chapter is distributed under the terms of the Creative Commons Attribution-NonCommercialShareAlike-3.0 License, which permits use, distribution and reproduction for non-commercial purposes, provided the original is properly cited and derivative works building on this content are distributed under the same license. 